\title{
ОСОБЛИВОСТІ СТАНУ ПРООКСИДАНТНОЇ СИСТЕМИ ПРИ ЕКСПЕРИМЕНТАЛЬНОМУ ПЕРИТОНІТІ НА ТЛІ ЦУКРОВОГО ДІАБЕТУ
}

Вступ. Гострий поширений перитоніт усе частіше призводить до розвитку тяжких післяопераційних ускладнень, збільшується відсоток летальних випадків. Цукровий діабет продовжує залишатися однією з актуальних проблем медицини, оскільки він є одним із найпоширеніших ендокринних захворювань зі стійкою тенденцією до зростання.

Мета дослідження - вивчити особливості прооксидантного статусу в організмі піддослідних тварин при змодельованому гострому поширеному перитоніті на тлі цукрового діабету порівняно зі щурами з експериментальним гострим поширеним перитонітом.

Методи дослідження. У роботі використовували 56 білих щурів. Цукровий діабет моделювали шляхом внутрішньоочеревинного введення стрептозотоцину фрірми "Sigmal" з розрахунку 7 мг на 100 г маси тіла щура, гострий поширений перитоніт - введення 0,5 мл 10 \% профрільтрованої калової суспензії в черевну порожнину досліджуваних тварин. Визначали показники прооксидантного статусу в сироватці крові на 1-шу, 3-тю, 7-му доби від початку моделювання перитоніту.

Результати й обговорення. Було доведено, що при гострому перитоніті на тлі цукрового діабету більшою мірою зростали маркери вільнорадикального окиснення порівняно з групою тварин зі змодельованим гострим перитонітом. Відмічали статистично значиме підвищення таких прооксидантних показників, як ТБК-активні продукти, гідропероксиди ліпідів, окисна модиорікація білків $(p<0,05)$.

Висновки. У тварин з гострим поширеним перитонітом на тлі цукрового діабету суттєво активуються вільнорадикальні процеси окиснення, що підтверджено статистично значимо вищими рівнями ТБК-активних продуктів, гідропероксидів ліпідів, окисної модифрікації білків нейтрального та основного характеру порівняно з групою тварин із змодельованим гострим поширеним перитонітом. Виявлена інтенсифрікація процесів окиснення вказує на значну активацію фракторів агресії організму при гострому поширеному перитоніті на тлі цукрового діабету.

КЛЮЧОВІ СЛОВА: гострий поширений перитоніт; цукровий діабет; прооксидантна система.

ВСТУП. Гострий поширений перитоніт (ГПП) та цукровий діабет (ЦД) залишаються пріоритетними медико-соціальними проблемами. Гострий поширений перитоніт усе частіше призводить до розвитку тяжких післяопераційних ускладнень, збільшується відсоток летальних випадків [1-3]. Така висока смертність зумовлена тим, що перитоніт виникає на тлі вже існуючих патологічних змін, спричинених коморбідним станом, особливістю перебігу якого $€$ відсутність чітких меж, швидке розповсюдження патологічного процесу по черевній порожнині, складність діагностики тощо. Усе це значно ускладнює перебіг ГПП і призводить до незадовільних результатів його лікування $[4,5]$.

() І. Я. Дзюбановський, Б. М. Вервега, С. Р. Підручна, Н. А. Мельник, 2018.
Разом із тим, на сьогодні цукровий діабет залишається найпоширенішою ендокринною патологією зі стійкою тенденцією до зростання. Поряд $з$ онкологічними і серцево-судинними захворюваннями він є однією з найчастіших причин інвалідизації та смертності хворих [6, 7]. Упродовж останніх десяти років поширеність ЦД в Україні зросла в 1,5 раза і нараховує до одного мільйона хворих. Безсумнівним на сьогодні вважають той фракт, що за умов цукрового діабету виникає високий ризик розвитку макро- і мікросудинних порушень із гнійно-запальними та некротичними процесами. Незважаючи на те, що за останні роки досягнуто певних успіхів у вивченні патогенезу ГПП та ЦД, донині не з'ясовано роль процесів ліпопероксидації при поєднаній патології $[8,9]$. 
Результати досліджень останніх років експериментально довели ключову роль пероксидного окиснення ліпідів (ПОЛ) у розвитку токсичної гіпоксії за умов цілого ряду патологічних станів, зокрема гострого поширеного перитоніту. Високий рівень ПОЛ - загальна неспецисрічна реакція організму на вплив стресових чинників, які стимулюють утворення і накопичення вільних радикалів [10, 11]. Наслідком посилення пероксидного окиснення ліпідів $є$ мембранотоксичний ефект, що призводить до дезінтеграції клітин. Оскільки ЦД супроводжується порушенням усіх видів обміну речовин, виснаженням системи антиоксидантного захисту, доцільним було вивчення особливостей однієї з патогенетичних ланок ГПП, який виник на тлі ЦД.

Мета дослідження - вивчити особливості прооксидантного статусу в організмі піддослідних тварин при змодельованому гострому поширеному перитоніті на тлі цукрового діабету порівняно зі щурами з експериментальним гострим поширеним перитонітом.

МЕТОДИ ДОСЛІДЖЕННЯ. Експерименти виконано на базі Центральної науково-дослідної лабораторії Тернопільського державного медичного університету імені І. Я. Горбачевського (свідоцтво про атестацію від 17.12.2007 р. № 000478).

Під час досліджень використано 56 білих щурів, яких поділили на 3 групи: основну групу 24 тварини зі змодельованим ГПП на тлі Цд; групу порівняння - 24 тварини зі змодельованим перитонітом; контрольну групу - 8 інтактних тварин, яких утримували в стандартних умовах віварію. Усі порівнювані групи тварин були репрезентативними за масою, статтю і віком. IHсулінозалежну фрорму цукрового діабету 1 типу в щурів основної групи, подібну до інсулінозалежної форми цукрового діабету 1 типу в людини, викликали шляхом одноразового внутрішньоочеревинного введення стрептозотоцину фрірми "Sigmal" з розрахунку 7 мг на 100 г маси тіла піддослідної тварини (приготованого на 0,1 М цитратному буфрері, $\mathrm{pH}=4,5$ ). Розвиток ЦД протягом 2-х тижнів контролювали за зростанням рівня глюкози в крові, який вимірювали глюкозооксидазним методом. Тваринам контрольної групи замість стрептозотоцину вводили підшкірно стерильний 0,9 \% розчин натрію хлориду [12].

На 14-ту добу після введення стрептозотоцину щурам основної групи внутрішньоочеревинно вводили $10 \%$ розчин калової суспензії (пул калу від 20 тварин у 0,9 \% розчині натрію хлориду) в дозі 0,5 мл на 100 г маси тіла. Щурам групи порівняння лише підшкірно вводили калову суспензію.
Спостереження проводили на 1-шу, 3-тю і 7-му доби від початку моделювання перитоніту. Для виконання досліджень використовували цільну кров та сироватку крові.

Експериментальні дослідження проводили з дотриманням загальних правил і положень Європейської конвенції про захист хребетних тварин, що використовуються для дослідних та інших наукових цілей (Страсбург, 1986), Загальних етичних принципів експериментів на тваринах (Київ, 2001) та Закону України "Про захист тварин від жорстокого поводження" (2006).

Про стан ПОЛ у різні терміни експерименту судили за рівнями ТБК-активних продуктів (ТБК-АП), гідропероксидів ліпідів (ГПЛ) та окисної модифрікації білків нейтрального й основного характеру (ОМБ ${ }_{370}$ та ОМБ $_{430}$ відповідно).

Рівень ТБК-активних продуктів визначали за методом В. М. Орєховича в модифрікації Л. І. Андреєвої [13]. Принцип методу визначення концентрації ТБК-АП полягає в їх здатності при взаємодії з тіобарбітуровою кислотою в кислому середовищі утворювати забарвлений комплекс, інтенсивність якого адекватна вмісту ТБК-активних продуктів. У центрифужні пробірки наливали по 1 мл дистильованої води, 0,5 мл плазми, 2 мл $30 \%$ розчину трихлороцтової кислоти, 0,2 мл $5 \mathrm{M} \mathrm{HCl,} 2$ мл тіобарбітурової кислоти і витримували 15 хв на водяній бані при $100{ }^{\circ} \mathrm{C}$. Рівень ТБК-АП вимірювали спектрофотометричним методом та виражали в ммоль/л.

Вміст гідропероксидів також визначали спектросоотометричним методом [14], який ґрунтується на тому, що екстраговані гептан-ізопропіловою сумішшю ГПЛ мають відповідний максимум поглинання при довжині хвилі 232 нм. Його виражали в умовних одиницях екстинкції (ум. од.).

У процесі окисної модифрікації білків (ОМБ) плазми утворюються альдегідні й кетонні групи, які взаємодіють із 2,4-динітросренілгідразином 3 утворенням 2,4-динітрофренілгідразонів, що мають характерний спектр поглинання. Альдегідоі кетонопохідні нейтрального характеру реєструють при 370 нм $\left(\mathrm{OMБ}_{370}\right)$, а основного - 430 нм $\left(\mathrm{OMБ}_{430}\right)$, тому вміст ОМБ ${ }_{370}$ й ОМБ ${ }_{430}$ визначали за допомогою спектрофотометричного методу [15].

Статистичну обробку цифррових даних здійснювали за допомогою програмного забезпечення Excel i STATISTICA з використанням параметричних та непараметричних методів оцінки отриманих даних. Для всіх показників розраховували значення середньої арифрметичної вибірки (M), ії дисперсії і помилки середньої (m). Достовірність різниці значень між незалежними кількісними величинами при нормальному роз- 
поділі встановлювали за t-критерієм Стьюдента, в інших випадках - за допомогою U-критерію Манна -Уїтні (достовірними вважали відмінності при $\mathrm{p<0,05).}$

РЕЗУЛЬТАТИ Й ОБГОВОРЕННЯ. При дослідженні стану показників ПОЛ у тварин із змодельованим ГПП було виявлено лінійне статистично значиме зростання вмісту ТБК-АП залежно від збільшення термінів спостереження: в 1,3, 2 та 3,9 раза на 1-шу, 3-тю і 7-му доби відповідно (табл. 1) (р<0,05). Щодо ГПЛ, то їх вміст статистично значимо зменшувався відносно термінів спостереження: на 1-шу добу концентрація ГПЛ збільшилася в 3,9 раза порівняно 3 інтактними тваринами, на 3-тю добу - у 2,5 раза, на 7-му добу - у 2,2 раза ( $<<0,05)$. Це можна пояснити тим, що ГПЛ - це початкові продукти ПОЛ, які утворюються в ранні терміни ураження, ТБК-АП є кінцевими продуктами ПОЛ (альдегіди, кетони), і вони утворюються в пізні терміни ураження.
Концентрація окисномодиорікованих білків (як нейтрального - ОМБ ${ }_{370}$, так і основного характеру - ОМБ ${ }_{430}$ ) у тварин із змодельованим ГПП також статистично значимо зростала відповідно до збільшення термінів спостереження порівняно $з$ інтактною групою $(p<0,05)$.

У тварин основної групи процеси ПОЛ активувалися більшою мірою порівняно з групою порівняння (табл. 2). Вміст ТБК-АП на 1-шу добу спостереження підвищився у 2 рази відносно інтактної групи та на 55,9 \% порівняно з групою щурів із змодельованим ГПП; на 3-тю добу їх концентрація зросла у 3,4 раза і на $68,9 \%$, а на 7-му добу - в 7,8 раза та на 102,9 \% відповідно ( $p<0,05)$. Рівень ГПЛ у тварин з експериментальним ГПП на тлі ЦД зменшувався відносно збільшення термінів спостереження і був статистично значимо вищим від такого показника групи щурів із змодельованим ГПП ( $<<0,05)$.

Вміст продуктів ОМБ нейтрального $\left(\mathrm{OMБ}_{370}\right)$ та основного $\left(\mathrm{OMБ}_{430}\right)$ характеру в щурів основ-

Таблиця 1 - Показники активності пероксидного окиснення ліпідів у крові щурів з гострим поширеним перитонітом $(\mathrm{M} \pm \mathrm{m})$

\begin{tabular}{|c|c|c|c|c|}
\hline \multirow{3}{*}{ Показник } & \multicolumn{4}{|c|}{ Група піддослідних тварин } \\
\hline & \multirow{2}{*}{$\begin{array}{c}\text { інтактні } \\
(n=8)\end{array}$} & \multicolumn{3}{|c|}{ тварини з гострим поширеним перитонітом $(\mathrm{n}=24)$} \\
\hline & & 1-ша доба (n=8) & 3-тя доба $(n=8)$ & 7-ма доба $(n=8)$ \\
\hline ТБК-АП, ммоль/л & $1,90 \pm 0,12$ & $2,52 \pm 0,29^{\#}$ & $3,80 \pm 0,50^{\#}$ & $7,33 \pm 0,76^{\#}$ \\
\hline ГПЛ, ум. од. & $1,26 \pm 0,12$ & $4,91 \pm 0,29^{\#}$ & $3,16 \pm 0,33^{\#}$ & $2,78 \pm 0,37^{\#}$ \\
\hline $\mathrm{OMБ}_{370}$, ммоль/л & $0,71 \pm 0,13$ & $0,95 \pm 0,10^{\#}$ & $1,25 \pm 0,07^{\#}$ & $1,53 \pm 0,07^{\#}$ \\
\hline $\mathrm{OMБ}_{430}$, мМОль/л & $0,77 \pm 0,11$ & $0,99 \pm 0,09^{\#}$ & $1,28 \pm 0,05^{\#}$ & $1,52 \pm 0,11^{\#}$ \\
\hline
\end{tabular}

Примітка. " - достовірність різниці стосовно таких показників групи інтактних тварин.

Таблиця 2 - Показники активності пероксидного окиснення ліпідів у крові щурів з гострим поширеним перитонітом на тлі цукрового діабету (M $\pm \mathrm{m})$

\begin{tabular}{|c|c|c|c|c|}
\hline \multirow{3}{*}{ Показник } & \multicolumn{4}{|c|}{ Група піддослідних тварин } \\
\hline & \multirow{2}{*}{$\begin{array}{l}\text { інтактні } \\
(n=8)\end{array}$} & \multicolumn{3}{|c|}{$\begin{array}{c}\text { тварини з гострим поширеним перитонітом } \\
\text { на тлі цукрового діабету }(\mathrm{n}=24)\end{array}$} \\
\hline & & 1-ша доба (n=8) & 3-тя доба (n=8) & 7-ма доба (n=8) \\
\hline ТБК-АП, ммоль/л & $1,90 \pm 0,12$ & $\begin{array}{l}3,93 \pm 0,29^{\#} \\
{ }^{*} p<0,05\end{array}$ & $\begin{array}{c}6,42 \pm 0,88^{\#} \\
{ }^{*} p<0,05 \\
{ }^{\#} p<0,05\end{array}$ & $\begin{array}{c}14,87 \pm 0,76^{\#} \\
{ }^{*} p<0,05 \\
{ }^{\#} p<0,05 \\
* * p<0,05\end{array}$ \\
\hline ГПЛ, ум. од. & $1,26 \pm 0,12$ & $\begin{array}{l}7,12 \pm 0,39^{\#} \\
* p<0,05\end{array}$ & $\begin{array}{c}6,41 \pm 0,50^{\#} \\
{ }^{*} p<0,05 \\
{ }^{\#} p<0,05\end{array}$ & $\begin{array}{c}4,71 \pm 0,477^{\#} \\
{ }^{*} p<0,05 \\
{ }^{*} p<0,05 \\
{ }^{* *} p<0,05\end{array}$ \\
\hline $\mathrm{OMБ}_{370}$, мМОль/л & $0,71 \pm 0,13$ & $\begin{array}{l}1,22 \pm 0,10^{\#} \\
* \mathrm{p}<0,05\end{array}$ & $\begin{array}{c}1,53 \pm 0,12^{\#} \\
{ }^{*} p<0,05 \\
{ }^{\#} p<0,05\end{array}$ & $\begin{array}{c}1,91 \pm 0,14^{\#} \\
{ }^{*} p<0,05 \\
{ }^{*} p<0,05 \\
{ }^{* \star} p<0,05\end{array}$ \\
\hline $\mathrm{OMБ}_{430}$, ммоль/л & $0,77 \pm 0,11$ & $\begin{array}{l}1,31 \pm 0,09^{\#} \\
{ }^{*} p<0,05\end{array}$ & $\begin{array}{c}1,60 \pm 0,13^{\#} \\
{ }^{*} p<0,05 \\
{ }^{\#} p<0,05\end{array}$ & $\begin{array}{c}1,90 \pm 0,08 * \\
{ }^{*} p<0,05 \\
{ }^{*} p<0,05 \\
{ }^{* *} p<0,05\end{array}$ \\
\hline
\end{tabular}

Примітки:

1. \# - достовірність різниці стосовно таких показників групи інтактних тварин.

2. * - достовірність різниці стосовно таких показників групи порівняння.

3. \# - достовірність різниці стосовно таких показників групи тварин на 1-шу добу спостереження.

4. ** - достовірність різниці стосовно таких показників групи тварин на 3-тю добу спостереження. 
ної групи лінійно зростав порівняно з інтактними тваринами: на 71,8 і 70,1 \% - на 1-шу добу; на 115,5 та 107,8 \% - на 3-тю; на 169,0 і 146,8 \% на 7-му, він був статистично значимо вищим від таких показників групи тварин із змодельованим гПП (p<0,05).

Отже, у тварин з експериментальним ГПП на тлі ЦД процеси пероксидного окиснення ліпідів більш інтенсивні порівняно зі щурами із змодельованим гострим поширеним перитонітом.

\section{СПИСОК ЛІТЕРАТУРИ}

1. Дзюбановський І. Я. Синдром поліорганної недостатності та його корекція у хворих на гострий поширений перитоніт / І. Я. Дзюбановський, Б. О. Мігенько // Укр. Журн. Хірургії. - 2009. - № 2. - С. 56-59.

2. Білик І. І. Гострий перитоніт як ускладнення гострого апендициту / І. І. Білик // Клініч. та експерим. патологія. - 2016. - № 1 (43). - С. 187-189.

3. Гринчук Ф.В.Патогенетичні, клінічні і тактичні особливості при перитоніті та поєднаній патології / Ф. В. Гринчук // Харк. хірург. школа. - 2014. № 6 (44). - C. 47-49.

4. Spirt M. J. Complicated intra-abdominal infections: a focus on appendicitis and diverticulitis / M. J. Spirt // Postgrad. Med. - 2010. - 122, No. 1. - P. 39-51.

5. Kimura W. Problems and therapeutic strategy for emergen cy operation of the abdomen in the aged / W. Kimura, M. Mizutani, A. Fuse // Nippon Ronen Igakkai Zasshi. - 2014. - 41, No. 6. - P. 660-665.

6. Немцова В. Д. Сахарный диабет и внезапная смерть: решенные и нерешенные вопросы / В. Д. Немцова // Світ медицини та біології. - 2015. - № 2 (50). C. 206-211.

7. Gliclazide treatment lowers serum ICAM-1 levels in poorly controlled type 2 diabetic patients / N. Papanas, D. Tziakas, G. Chalikias [et al.] // Diabetes \& Metabolism. 2016. - 32, No. 4. - Vol. 344-349.

8. Associations of mortality and diabetes complications in patients with type 1 and type 2 diabetes I
ВИСНОВКИ. У тварин з гострим поширеним перитонітом на тлі цукрового діабету суттєво активуються вільнорадикальні процеси окиснення, що підтверджено статистично значимо вищими рівнями ТБК-активних продуктів, гідропероксидів ліпідів, окисної модифрікації білків нейтрального та основного характеру порівняно з групою тварин із змодельованим гострим поширеним перитонітом. Виявлена інтенсифрікація процесів окиснення вказує на значну активацію фракторів агресії організму при гострому поширеному перитоніті на тлі цукрового діабету.

M. Cusick, A. D. Meleth, E. Agron [et al.] // Diabetes Care. - 2005. - 28, No. 3. - P. 617-625.

9. Кисляк О. А. Сахарный диабет 2 типа, артериальная гипертензия и риск сердечно-сосудистых осложнений / О. А. Кисляк, Т. О. Мышляева, Н. В. Малышева // Сахарный диабет. - 2008. - № 1. C. $45-49$.

10. Нагорная Н. В. Оксидативный стресс: влияние на организм человека, методы оценки / Н. В. Нагорная, Н. А. Четверик // Здоровье ребенка. - 2010. № 2 (23). - C. 140-145.

11. Lee W. Jennifer Future applications of antioxidants in premature infants / J. W. Lee, J. M. Davis // Curr. Opin. Pediatr. Author Manuscript. - 2011. - No. 23 (2). P. 161-166.

12. Доклінічні дослідження лікарських засобів / за ред. О. В. Стефанова. - К. : ВД “Авіцена”, 2001. $568 \mathrm{c.}$

13. Андреева Л. И. Модисрикация метода определения перекисей липидов в тесте с тиобарбитуровой кислотой / Л. И. Андреева, Л. А. Кожемякин, А. А. Кишкун // Лаб. дело. - 1988. - № 11. - С. 41-43.

14. Горячковський О. М. Клінічна біохімія в лабораторній діагностиці : довідковий посібник / О. М. Горячковський. - Одеса : Екологія, 2015. - 616 с.

15. Стальная И. Д. Современные методы в биохимии / И. Д. Стальная. - М. : Медицина, 1977. C. 63-64.

\section{REFERENCES}

1. Dziubanovskyi, I.Ya. \& Mihenko, B.O. (2009). Syndrom poliorhannoi nedostatnosti ta yoho korektsiia u khvorykh na hostryi poshyrenyi perytonit [The syndrome of multiple organ failure and its correction in patients with acute common peritonitis]. Ukr. Zhurn. Khirurhii - Ukr. Journal of Surgery, 2, 56-59 [in Ukrainian].
2. Bilyk, I.I. (2016). Hostryi perytonit yak uskladnennia hostroho apendytsytu [Acute peritonitis as a complication of acute appendicitis]. Klinichna ta eksperymentalna patolohiia -Clinical and Experimental Pathology, 1 (43), 187-189 [in Ukrainian].

3. Hrynchuk, F.V. (2014). Patohenetychni, klinichni i taktychni osoblyvosti pry perytoniti ta poiednanii patolohii 
[Pathogenetic, clinical and tactical features in peritonitis and combined pathology]. Kharkivska khirurhichna shkola - Kharkiv Surgical School, 6 (44), 47-49 [in Ukrainian].

4. Spirt, M.J. (2010). Complicated intra-abdominal infections: a focus on appendicitis and diverticulitis. Postgrad. Med., 122, 1, 39-51.

5. Kimura, W., Mizutani, M., \& Fuse, A. (2014). Problems and therapeutic strategy for emergency operation of the abdomen in the aged. Nippon Ronen Igakkai Zasshi, 41, 6, 660-665.

6. Nemtsova, V.D. (2015). Sakharnyy diabet i vnezapnaya smert: reshennyye i nereshennyye voprosy [Diabetes mellitus and sudden death: resolved and unresolved issues]. Svit medytsyny ta biolohi - World of Medicine and Biology, 2 (50), 206-211 [in Russian].

7. Papanas, N., Tziakas, D., Chalikias, G., Floros, D., Trypsianis, G., Papadopoulou, E., ... \& Hatseras, D. (2016). Gliclazide treatment lowers serum ICAM-1 levels in poorly controlled type 2 diabetic patients. Diabetes \& Metabolism, 32, 4, 344-349.

8. Cusick, M., Meleth, A.D., Agron, E., Fisher, M.R., Reed, G.F., Knatterud, G.L., \& Chew, E.Y. (2005). Associations of mortality and diabetes complications in patients with type 1 and type 2 diabetes. Diabetes Care, 28, 3, 617-625.

9. Kislyak, O.A., Myshlyayeva, T.O., \& Malysheva, N.V. (2008). Sakharnyy diabet 2 tipa, arterialnaya gipertenziya i risk serdechno-sosudistykh oslozhneniy [Type 2 diabetes mellitus, arterial hypertension and the risk of cardiovascular complications]. Sakharnyy diabet Diabetes, 1, 45-49 [in Russian].

10. Nagornaya, N.V., \& Chetverik, N.A. (2010). Oksidativnyy stress: vliyaniye na organizm cheloveka, metody otsenki [Oxidative stress: effect on the human body, assessment methods]. Zdorovye rebenka - Child Health, 2 (23), 140-145 [in Russian].

11. Lee, J.W., \& Davis, J.M. (2011). Future applications of antioxidants in premature infants. Curr. Opin. Pediatr. Author Manuscript, 23 (2), 161-166.

12. Stefanov, O.V. (Ed.). (2001). Doklinichni doslidzhennia likarskykh zasobiv [Pre-clinical research of drugs]. Kyyiv: VD "Avitsena" [in Ukrainian].

13. Andreyeva, L.I., Kozhemyakin, L.A., \& Kishkun, A.A. (1988). Modifikatsiya metoda opredeleniya perekisey lipidov $v$ teste s tiobarbiturovoy kislotoy [Modification of the method for determining lipid peroxides in a test with thiobarbituric acid]. Lab. delo - Lab. Matter, 11, 41-43 [in Russian].

14. Horyachkovskyi, O.M. (2015). Klinichna biokhimiia $v$ laboratornii diahnostytsi: dovidkovyi posibnyk [Clinical biochemistry in laboratory diagnostics: reference book]. Odesa: Ekolohiia [in Ukrainian].

15. Stalnaya, I.D. (1977). Sovremennyye metody $v$ biokhimii [Modern methods in biochemistry]. Moskow: Meditsina [in Russian].

И. Я. Дзюбановский ${ }^{1}$ Б. М. Вервега ${ }^{2}$, С. Р. Пидручная ${ }^{1}$, Н. А. Мельник ${ }^{1}$ ТЕРНОПОЛЬСКИЙ ГОСУДАРСТВЕННЫЙ МЕДИЦИНСКИЙ УНИВЕРСИТЕТ ИМЕНИ И. Я. ГОРБАЧЕВСКОГО ЛЬВОВСКИЙ НАЦИОНАЛЬНЫЙ МЕДИЦИНСКИЙ УНИВЕРСИТЕТ ИМЕНИ ДАНИЛА ГАЛИЦКОГО

\section{ОСОБЕННОСТИ СОСТОЯНИЯ ПРООКСИДАНТНОЙ СИСТЕМЫ ПРИ ЭКСПЕРИМЕНТАЛЬНОМ ПЕРИТОНИТЕ НА ФОНЕ САХАРНОГО ДИАБЕТА}

\section{Резюме}

Вступ. Острый распространенный перитонит все чаще приводит к развитию тяжелых послеоперационных осложнений, увеличивается процент летальных случаев. Сахарный диабет продолжает оставаться одной из актуальных проблем медицины, поскольку он является одним из самых распространенных эндокринных заболеваний со стойкой тенденцией к росту.

Цель исследования - изучить особенности прооксидантного статуса в организме подопытных животных при смоделированном остром распространенном перитоните на фроне сахарного диабета по сравнению с крысами с экспериментальным острым распространенным перитонитом.

Методы исследования. В работе использовали 56 белых крыс. Сахарный диабет моделировали путем внутрибрюшинного введения стрептозотоцина фрирмы "Sigmal" из расчета 7 мг на 100 г массы тела крысы, острый распространенный перитонит - введения 0,5 мл 10 \% просрильтрованной каловой суспензии в брюшную полость исследуемых животных. Определяли показатели прооксидантного статуса в сыворотке крови на 1-е, 3-е и 7-е сутки от начала моделирования перитонита.

Результаты и обсуждение. Было доказано, что при остром перитоните на фроне сахарного диабета в большей мере возрастали маркеры свободнорадикального окисления по сравнению с группой животных со смоделированным острым перитонитом. Отмечали статистически значимое повышение таких прооксидантных показателей, как ТБК-активные продукты, гидроперекиси липидов, окислительная модификация белков $(p<0,05)$.

Выводы. У животных с острым распространенным перитонитом на фроне сахарного диабета существенно активизируются свободнорадикальные процессы окисления, что подтверждено статисти- 
чески значимо более высокими уровнями ТБК-активных продуктов, гидроперекисей липидов, окислительной модификации белков нейтрального и основного характера по сравнению с группой животных со смоделированным острым распространенным перитонитом. Обнаруженная интенсификация процессов окисления указывает на значительную активацию фракторов агрессии организма при остром распространенном перитоните на фроне сахарного диабета. система

КЛЮЧЕВЫЕ СЛОВА: острый распространенный перитонит; сахарный диабет; прооксидантная

I. Ya. Dziubanovskyi ${ }^{1}$, B. M. Verveha ${ }^{2}$, S. R. Pidruchna ${ }^{1}$, N. A. Melnyk ${ }^{1}$ I. HORBACHEVSKY TERNOPIL STATE MEDICAL UNIVERSITY ${ }^{1}$ DANYLO HALYTSKYI LVIV NATIONAL MEDICAL UNIVERSITY²

\section{FEATURES OF THE STATE OF PROOXIDANT SYSTEM WHEN EXPERIMENTAL PERITONITIS AGAINST THE BACKGROUND OF DIABETES}

Summary

Introduction. Acute peritonitis increasingly leads to the development of severe postoperative complications, the percentage of fatal cases increases. Diabetes mellitus continues to be one of the urgent problems of medicine, because it is one of the most common endocrine diseases with a persistent tendency to grow.

The aim of the study - to learn the features of prooxidant status in the body of experimental animals with simulated acute peritonitis on the background of diabetes mellitus compared with animals with experimental acute peritonitis.

Research Methods. In the work we used 56 white rats. Diabetes mellitus was modeled by intraperitoneal administration of streptozotocin from Sigmal (7 mg per $100 \mathrm{~g}$ of animal's body), acute disseminated peritonitis administration of $0.5 \mathrm{ml}$ of $10 \%$ filtered fecal suspension into the abdominal cavity of the studied animals. Determined indicators of prooxidant status in serum at 1, 3 and 7 days from the beginning of the simulated peritonitis.

Results and Discussion. It was proved that in animals with acute peritonitis on the background of diabetes mellitus, free radical oxidation processes are significantly activated, which is confirmed by statistically significantly higher levels of TBA-active products, hydroperosids, oxidative modification of proteins compared to the group of animals with simulated acute peritonitis. The detected intensification of oxidation processes indicates a significant activation of the organism's aggression factors in acute peritonitis against the background of diabetes mellitus.

Conclusions. In animals with acute common peritonitis, free radical oxidation processes are significantly activating against the background of diabetes, which is confirmed by statistically significantly higher levels of TBAactive products, lipid hydro peroxides, and an oxidative modification of neutral and basic proteins compared to a group of animals with a pattern of acute common peritonitis. The revealed intensification of oxidation processes indicates a significant activation of the aggression of the organism in acute common peritonitis on the background of diabetes mellitus.

KEY WORDS: acute diffuse peritonitis; diabetes mellitus; prooxidant system.

Отримано 10.10.18

Адреса для листування: Б. М. Вервега, вул. Соколина, 23, Львів, 79038, Україна, e-mail: danaverveha@gmail.com. 